\title{
Involvement of Girls in Leadership in Primary Schools in Voi Sub-county, Kenya
}

\author{
Dr. Florence Kanorio Kisirkoi \\ Maasai Mara University, Narok, Kenya
}

\author{
Angela Ndunge Kamanga \\ Taita Taveta County Education Office, Taita Taveta, Kenya
}

\begin{abstract}
Women in Kenya are underrepresented in decision-making positions, which appears as a remnant of persisting cultural gender roles that limit women from participating in activities critical for personal, societal, and national development. Such retrogressive ideas regarding a large number of the country's citizens have to be addressed early in the life of a girl to build in girls' self-esteem and facilitate them to develop leadership skills. This study investigated the extent to which girls in primary schools in Voi sub-county are involved in leadership in their schools. The study was based on the 2010 Kenya's constitution which ruled that no more than two-thirds of elected or appointed public institutions leaders should consist of one gender. The new legal framework seeks to break down the barriers women face in realizing their political, civil, economic, and social rights. It also ensures that women are involved in decision-making at all levels of government. In this study, data was collected from three mixed primary schools in Voi sub-county given codes A, B, and C. School A had a total of 470 pupils; 225 were boys and 245 were girls and the school had 21 leadership positions. The findings showed that the majority $14(66.7 \%)$ of the leadership positions were occupied by boys while the few 7 (33.3\%) were occupied by girls. In school B, there were a total of 1,056 pupils; 498 were boys and 558 were girls. There were 13 leadership positions. The majority of the positions 7 (53.8\%) were occupied by boys and minority $6(46.2 \%)$ were occupied by girls. In school C, there were a total of 1,450 pupils and 680 were boys and 770 girls. There were 13 leadership positions. The majority 7 (53.8\%) of the positions were occupied by boys while $6(46.2 \%)$ were occupied by girls. In all the schools, there were more girls than boys but boys occupied more leadership positions than girls. Boys also took senior positions and girls were their deputies and were not as active as boys in areas such as class discussions and debate. It was recommended that conscious effort should be made to develop leadership skills in girls during their formative years.
\end{abstract}

Keywords: leadership, decision making, constitution, underrepresented, gender roles

\section{Introduction}

The Kenyan Government has been committed to elimination of challenges facing the girl child. This has been clearly evidenced through the country's participation in both the international and national forums on gender; hence a partner in the global commitment to resolving issues that are related to gender sensitivity and equity. However, Kenyan women have not been fully given a voice in key decision making positions. This has limited their participation in national development despite the fact that they constitute half of the country's

Dr. Florence Kanorio Kisirkoi, Ph.D., Curriculum Instruction and Educational Management, Maasai Mara University.

Angela Ndunge Kamanga, Master of Education (Science Education), Ministry of Education Science and Technology (MOEST), Taita Taveta County Education Office. 
population and play a crucial role in national development.

This study was guided by the Kenyan constitution of 2010 Chapter 27 on equality and freedom from discrimination; section 3 which states that women and men have the right to equal treatment, including the right to equal opportunities in political, economic, cultural, and social spheres (Kituo Cha Sheria \& Kenya Land Alliance, 2012). The Millennium Development Goals proposes the call for gender equality in education and access to social, economic, and political opportunities by 2015 (UNESCO, 2002). The UNESCO World Education Forum (2015) Incheon Declaration, recognizes the importance of gender equity in achieving education for all and declares commitment to support gender sensitive policies and eliminating gender based discrimination. This called for the strengthening of institutional structures to address gender equality and reinforce a mechanism of monitoring gender equality implementation processes.

Frowin, Marema, Prosper, and Rose (2005) noted that the failure to empower and fully represent women in key national positions has also been replicated in institutions of learning appearing as unrelenting gender roles. This has restrained their participation in activities and forums that would have been significant in realizing their full potential. Lack of empowerment has affected negatively the girls' social development leading to display of lack of self-confidence, assertiveness, and self-esteem. In addition, the fear to challenge, injustices, inability to make decisions, and lack of courage to speak out have also played a great role in silencing girls and women in many Kenyan communities (Frowin, Marema, Prosper, \& Rose, 2005). The school provides an environment that if well utilized and managed by the school administration and other stakeholders could provide an excellent opportunity for empowering the girl child and developing in her desirable leadership skills. This is through ensuring equality in representation in the school pupils' council.

The involvement of girls in top school leadership roles would result in a powerful effect on their future aspirations to participate in key decision making positions in the community and the country. There was need to conduct a study to establish whether girls in primary schools in Voi sub-county were involved in school leadership positions. The gender beliefs that still prevail in our schools need to be addressed and empower the girl child through involving them not only in leadership but also in senior leadership positions in the pupils' council. The objective of this study was to establish the extent to which girls in primary schools in Voi sub-county were involved in leadership in their schools and in class participation.

This study was based on the socialization theory by Charles Horton Cooley (1902) who argued that, human beings need social experiences to learn their culture and to survive. In the looking-glass self psychological concept, a person's self grows out of society's interpersonal relations and the perceptions of others. In this case, the boys and girls could be possibly shaped based on the expectations and reinforcement of their parents' teachers and the community at large. Subsequently, the pattern of leadership evidenced in the schools grossly determines the kind of people girls and boys grow to become in future. Socialization of the boys and the girls tend to have significant contribution to their participation in leadership positions and class participation. Their cultural variability is manifested in their actions, behaviour, and their interest at individual level through socialization by parents, teachers, extended families, and the extended societal networks. The gender lenses used in this study was the women empowerment framework by Longwe (1998). It argues that the school system contributes to women's insubordination. It is intended to measure the extent to which women have been empowered through gaining access to participation in and control of the progress process (Longwe, 1998). This study assessed only two levels of the framework which are the participation and control. Participation refers to equal representation in decision making, whether in policy making or administration. 
In this study, which is within the school situation, participation would be taken to mean that there is equality of opportunity or equal voice in leadership for both girls and boys. Control level in this study relates to equal control over decision making. In this study, this would mean that there is a sense of balance between the boys and girls hence no side dominates. For that reason, all the pupils in the school need to have equal control of what they are entitled to. For example, there should be equal number of girls and boys leaders in the students' council, in school clubs, group discussions, and debates among others.

The study was also backed by the Kenya's constitution of 2010 which ruled that no more than two-thirds of elected or appointed public institutions' leaders should consist of one gender and this legal framework seeks to break down the barriers women face in realizing their political, civil, economic, and social rights. It also ensures that women are involved in decision-making at all levels of the government.

\section{Status of Women and Leadership in Kenya}

Women in Kenya are more than half the population of the country but they are grossly underrepresented in leadership and decision making positions in the country (African Development Bank, African Development Fund, Kenya, 2007). This is regardless the fact that they play multiplicity of roles which contribute greatly to national development. They combine family duties, office work or run business or agricultural work and dominate the informal sector, bring up children yet they have limited access to financial resources and decision making positions (Munyau, 2013).

Regarding education, different views about the worth of educating girls and regarding the precise roles for the girls at their prime of life, interests of the community, and attitudes and aspirations of the girls themselves act as barriers to their social development (Leach, FIiscian, Kadzmira, Leman, \& Machakanja, 2003). However, educated girls bring up planned healthier families and ensure education of their children. Consequently, there was need for investigation of girls' involvement in leadership in schools, in order to come up with early interventions, at the primary school level.

There is report that there is a clear male statistical dominance in leadership position which is a clear indication that formative years are least represented in political and economic spheres due to societal limited participation and lack of opportunities (Ministry of Gender, Sports, Culture \& Social Services, 2005). Therefore, the accountability of ensuring that the aspirations and hopes of girls during their formative years are met is responsibility of every Kenyan citizen and school should play a great role. Sheryl (2013) points out that leaders emerge in schools and some get opportunities to get real recognition to practice leadership skills before leaving school. This was the drive for this study. In the school environment, some clubs play a significant role in creating awareness to the rights of the girl child (Flowin, Marema, Prosper, \& Rose, 2005). This provides a good platform for the girls to participate and air their views among the boys hence providing exposure for them to develop self-confidence which will eventually boost their self-esteem and as future leaders address needs of the entire society. Schools can model gender inclusive leaders if those in authority are purposeful to model and send the right message in their words and actions (Sheryl, 2013).

\section{Method}

This study employed case study approach. Three mixed primary schools from Voi sub-county were used in this study. The study investigated the extent to which girls in three mixed primary schools were involved in leadership in their schools. It also established the level of class participation of boys and girls. 


\section{Data Collection}

Data was collected using a questionnaire. The schools were assigned codes A, B, and C. School A had a total of 470 pupils; 225 were boys and 245 were girls and the school had 21 leadership positions. In school B, there were a total of 1,056 pupils; 498 were boys and 558 were girls and had 13 leadership positions. In school $\mathrm{C}$, there were a total of 1,450 pupils and 680 were boys and 770 girls. There were 13 leadership positions. Descriptive statistics was used to analyze the data in form of percentages that illustrated the sets of categories formed from the data. Descriptive statistics enabled the researcher to explain a distribution of measurements and summarize data as advised in Mugenda and Mugenda (2003), and Fain (1999).

\section{Results}

The findings of the study were presented in Table 1.

Table 1

Percentage of Girls and Boys in Leadership Positions

\begin{tabular}{|c|c|c|c|c|c|c|}
\hline \multirow[t]{2}{*}{ Item/questionnaire } & \multicolumn{2}{|c|}{ School A } & \multicolumn{2}{|c|}{ School B } & \multicolumn{2}{|c|}{ School C } \\
\hline & $\begin{array}{l}\text { Male } \\
(\mathrm{N}=225)\end{array}$ & $\begin{array}{l}\text { Female } \\
(\mathrm{N}=245)\end{array}$ & $\begin{array}{l}\text { Male } \\
(\mathrm{N}=498)\end{array}$ & $\begin{array}{l}\text { Female } \\
(\mathrm{N}=558)\end{array}$ & $\begin{array}{l}\text { Male } \\
(\mathrm{N}=680)\end{array}$ & $\begin{array}{l}\text { Female } \\
(\mathrm{N}=770)\end{array}$ \\
\hline Total number of pupils in your school & 470 & & 1,056 & & 1,450 & \\
\hline $\begin{array}{l}\text { Total number of leadership positions in } \\
\text { the pupils council }\end{array}$ & 21 & & 13 & & 13 & \\
\hline Boys in school leadership & $14(66.7 \%)$ & & $7(53.8 \%)$ & & $7(53.8 \%)$ & \\
\hline Girls in school leadership & $7(33.3 \%)$ & & $6(46.2 \%)$ & & $6(46.2 \%)$ & \\
\hline
\end{tabular}

To assess the involvement of the girls and boys in leadership position in the schools, a questionnaire was used. The results revealed that, in school A with a total of 470 pupils, the majority 14 (66.7\%) of the leadership positions were occupied by boys while the few $7(33.3 \%)$ positions were occupied by girls. The same trend was observed in school B where there were a total of 1,056 pupils; 498 were boys and 558 were girls and there were 13 leadership positions. The majority of the positions were taken by boys. This trend was also observed in school $\mathrm{C}$ whereby the majority of the positions 7 (53.8\%) were occupied by boys and minority $6(46.2 \%)$ were occupied by girls. It was observed that in each of the three schools, there were more girls than boys but in each case the number of leadership positions assigned to the boys was higher than that assigned to the girls.

It was also established that all president positions in the three schools were occupied by boys. All deputy presidents in the three schools were girls. Girls were found to be most active in prayer groups while boys were more active in debate and class discussion. Girls were found to be active in class discussions in lower primary but the participation dwindles as they progress to upper classes.

The findings tend to agree with Frowin, Marema, Prosper, and Rose (2005) who pointed out that the failure to empower and fully represent women in key national positions has also been replicated in institutions of learning appearing as unrelenting gender roles. It is also in agreement with Longwe (1998) who argued that the school system contributes to women's insubordination.

\section{Conclusion}

The representation of the girls in leadership was found to be lower than that of the boys. The girls only took the positions of deputy presidents in the school pupils' council. This clearly showed that the girls mostly took the backseat when it came to representation in leadership, a scenario that is well replicated in the societal 
roles of the men and women. The representation of the girls in leadership is a worrying trend that if not well addressed as early as at the primary school level, it could keep on showing up at the national level. There is low participation of women in leadership positions despite their large number in population and great role they play in national development and in bringing up the next generation. Therefore, there is a need for gender sensitization not only in our primary schools but also in all other learning institutions. The findings from this study therefore have great implications for the school administration and other education stakeholders. It is their role to ensure that there is equal representation of both gender groups in the school leadership in preparation of the girl and the boy child for future gender parity in leadership of the country. Therefore, there is a need for conscious effort to be made to develop leadership skills in girls as well as boys during their formative years. A longitudinal study could be conducted to follow up the students to secondary, tertiary, and employment to establish the trend it takes later in life. A study could also be conducted to stablish why girls were more active in lower primary and participation declines as they move on to upper classes.

\section{References}

African Development Bank, \& African Development Fund. (2007). Kenya country gender profile. Human Development Department (OSHD).

Boundless. (2015). Theories of socialization. In Boundless sociology. Retrieved September 3, 2015 from https://www.boundless.com/sociology/textbooks/boundless-sociology-textbook/socialization-4/theories-of-socialization-44/t heories-of-socialization-273-10450/

Cooley, C. H. (1902). Human nature and the social order (Revised ed.). The Mead Project. New York: Charles Scribner's Sons (1922). Retrieved January 18, 2005 from http://spartan.ac.brocku.ca/ lward/Cooley/Cooley_1902/Cooley_1902toc.html

Fain, J. A. (1999). Reading, understanding, and applying nursing research. Philadelphia, USA: F.A. Davis Company.

Kituo Cha Sheria, \& Kenya Land Alliance. (2012). The constitution of Kenya, 2010.

Leach, F., FIiscian, V., Kadzmira, E., Leman, E., \& Machakanja, P. (2003). An investigative study of the abuse of girls in African schools. Brighton: Sussex School of Education University of Sussex.

Longwe, S. (1998). Education for women's empowerment or schooling women's subordination? Gender and Development, 6(2), 19-26.

Ministry of Gender, Sports, Culture \& Social Services. (2005). The national youth policy.

Munyau, W. L. (2013). Gender issues affecting the girl child in Kenya. International Journal of Humanities, 3(4), 125-129.

Mugenda, O. M., \& Mugenda, A. G. (2003). Research methods: Quantitative and qualitative approaches. Nairobi, Kenya: ACTS Press.

Frowin, P., Marema, H., Prosper, M. L., \& Rose, N. (2005). Let us speak out. Empowering youth through “TUSOME”. A teachers handbook. Tanzania: University of Dar es Salaam.

Sheryl, S. (2013). Lean in: Women, work and the will to lead. New York: Alfred A. Knopf.

UNESCO. (2002). Education for all: Is the world on track? EFA Global Monitoring Report, Paris: UNESCO.

UNESCO World Education Forum. (2015). Incheon declaration. Education 2030: Towards inclusive and equitable quality education and lifelong learning for all. 